University of Nebraska - Lincoln

DigitalCommons@University of Nebraska - Lincoln

USDA National Wildlife Research Center - Staff Publications
U.S. Department of Agriculture: Animal and Plant Health Inspection Service

2008

\title{
Bird Use of Stormwater-Management Ponds: Decreasing Avian Attractants on Airports
}

\author{
Bradley F. Blackwell \\ United States Department of Agriculture, Animal and Plant Health Inspection Service, Wildlife Services, \\ National Wildlife Research Center \\ Laurence Schafer \\ United States Department of Agriculture, Animal and Plant Health Inspection Service, Wildlife Services \\ David Helon \\ United States Department of Agriculture, Animal and Plant Health Inspection Service, Wildlife Services, \\ National Wildlife Research Center \\ Michael Linnell \\ United States Department of Agriculture, Animal and Plant Health Inspection Service, Wildlife Services
}

Follow this and additional works at: https://digitalcommons.unl.edu/icwdm_usdanwrc

Part of the Environmental Sciences Commons

Blackwell, Bradley F.; Schafer, Laurence; Helon, David; and Linnell, Michael, "Bird Use of StormwaterManagement Ponds: Decreasing Avian Attractants on Airports" (2008). USDA National Wildlife Research Center - Staff Publications. 801.

https://digitalcommons.unl.edu/icwdm_usdanwrc/801

This Article is brought to you for free and open access by the U.S. Department of Agriculture: Animal and Plant Health Inspection Service at DigitalCommons@University of Nebraska - Lincoln. It has been accepted for inclusion in USDA National Wildlife Research Center - Staff Publications by an authorized administrator of DigitalCommons@University of Nebraska - Lincoln. 


\title{
Bird use of stormwater-management ponds: Decreasing avian attractants on airports
}

\author{
Bradley F. Blackwell ${ }^{\mathrm{a}, *}$, Laurence M. Schafer ${ }^{\mathrm{b}}$, David A. Helon ${ }^{\mathrm{a}}$, Michael A. Linnell ${ }^{\mathrm{b}}$ \\ a United States Department of Agriculture, Animal and Plant Health Inspection Service, Wildlife Services, National Wildife Research Center, \\ Ohio Field Station, 6100 Columbus Avenue, Sandusky, OH 44870, USA \\ b United States Department of Agriculture, Animal and Plant Health Inspection Service, Wildlife Services, \\ 720 O'Leary Street, NW, Olympia, WA 98502, USA
}

\section{A R T I C L E I N F O}

\section{Article history:}

Received 21 May 2007

Received in revised form 14 February 2008

Accepted 20 February 2008

Available online 11 April 2008

\section{Keywords:}

Airport

Avian use

Aviation hazard

Bird strike

Stormwater-management pond

Wildlife strike

\begin{abstract}
A B S T R A C T
Characteristics of stormwater-management ponds that contribute to avian hazards to aviation at airports have not been quantified. We selected 30 stormwater-management ponds (average 0.1 ha), approximately $50 \mathrm{~km}$ from Seattle-Tacoma International Airport, as surrogates to on-airport facilities. We conducted 46 weeks of avian surveys (between 14 February 2005 and 17 February 2006) and evaluated model fit of 6 a priori models relative to pond use by an avian group via Kullback-Leibler information. Our full model, composed of pond surface area (sa), ratio of area of open water to area of emergent and woody vegetation (ow:ew), perimeter irregularity, and geographic isolation, was among 3 best approximating models for pond use by 9 of 13 groups (within Anatidae, Ardeidae, Charadriidae, Columbidae, Accipitridae, Laridae, and Rallidae) considered. The full model and models lacking sa or ow:ew were indistinguishable in fit for a group composed of avian species considered hazardous to aviation. For models selected, Akaike weights (i.e., relative likelihoods) ranged from 0.869 to 0.994 . In contrast, relative likelihood for a mean model (i.e., a model including only an intercept) was $<10^{-4}$ for all groups. We suggest that designs of stormwatermanagement ponds at airports in the Pacific Northwest should minimize the pond perimeter via circular or linear designs. Also, ponds should be located so as to reduce the number and proximity of other water resources within $1 \mathrm{~km}$. For existing stormwater-management ponds at airports, we suggest reducing the availability of open water via covering or drawdown.
\end{abstract}

Published by Elsevier B.V.

\section{Introduction}

Airports must control the movement of stormwater away from runways, taxiways, and aprons to ensure the safety of aircraft operations. However, management of potential hazards to aviation safety is typically one of conflicting priorities for airport managers. Specifically, the containment of stormwater runoff can also create a wildlife attractant and, therefore, a potential collision hazard (U.S. Federal Aviation Administration, FAA, 2004). Wildlife collisions with aircraft are not rare, nor are these incidents insignificant relative to air safety or cost incurred (Cleary et al., 2007).

For example, from 1990 to 2005, 66392 wildlife collisions with aircraft were reported to the FAA; $97.5 \%$ of these incidents

\footnotetext{
* Corresponding author. Tel.: +1 4196250242.

E-mail addresses: bradley.f.blackwell@aphis.usda.gov (B.F. Blackwell), laurence.m.schafer@aphis.usda.gov (L.M. Schafer), david.a.helon@aphis.usda.gov (D.A. Helon), michael.a.linnell@aphis.usda.gov (M.A. Linnell).
}

involved birds. During this period, collisions between birds and aircraft (hereafter, bird strikes) resulted in the loss of nearly 65000 birds, including over 3500 raptors and 2600 waterfowl (Anatidae). In addition, the approximate cost to the civil aviation industry in the USA due to bird strikes exceeded $\$ 600$ million annually in direct monetary losses and associated costs (Cleary et al., 2007). Dolbeer (2006) demonstrated that for bird strikes $\leq 152 \mathrm{~m}$ above ground level (AGL), Passeriformes, gulls/terns (Laridae), doves/pigeons (Columbidae), and raptors (Falconiformes) were the species groups most frequently struck. For strikes $>152 \mathrm{~m}$ AGL, waterfowl, gulls/terns, Passeriformes, and vultures (Cathartidae) were the species groups most frequently struck. Notably, for strikes resulting in substantial damage to the aircraft (see Dolbeer et al., 2000; Cleary et al., 2007), 67\% occurred at $\leq 152$ m AGL (Dolbeer, 2006).

The FAA provides guidelines for wildlife hazard management within the air operations area (AOA), including control of potential wildlife attractants. The AOA consists of areas designated for takeoff, landing, and surface maneuvers of aircraft (see 14 CFR Part 139, Subpart D). Also, the FAA (2004) recommends that water runoff be 
held for a maximum of 48 hrs by use of "detention" ponds. However, characteristics of stormwater-management ponds that contribute to wildlife use have not been quantified (see, however, Adams et al., 1985a,b), unlike water resources in many natural systems.

Avian use of wetlands and other water bodies is governed by a myriad of factors including species ecology, season, region, as well as landscape- and local-scale effects. For example, Brown and Dinsmore (1986), working in Iowa, found that size and isolation of marshes accounted for $75 \%$ of the variation in avian species richness. The authors noted that species richness (e.g., species within Anatidae, Ardeidae, Emberizidae, Laridae, and Rallidae) was often greater in wetland complexes (20-30 ha for marsh and $>55$ ha of marsh complex within $5 \mathrm{~km}$ ), than in larger (up to $180 \mathrm{ha}$ ) isolated marshes. Gibbs et al. (1991), working in Maine, found that wetlands with an intermediate level of emergent cover (33-66\%) had greater avian species richness (see also Belánger and Courture, 1988; Creighton et al., 1997). Water-to-cover ratio (Weller and Spatcher, 1965) and water depth also contributed to avian use of the wetland. Similar to findings by Brown and Dinsmore (1986), Fairbairn and Dinsmore (2001), also working in Iowa, found that densities of 5 avian species (within families noted above), as well as overall species richness, were associated with a measure of the amount of wetland habitat within a 3-km buffer surrounding wetland complexes, indicating that the presence and abundance of some wetland bird species might be influenced by the amount of wetland habitat nearby. On lakes systems in Switzerland, Suter (1994) linked abundance and richness of various avifauna populations (including species of Anatidae and Rallidae common to North America and Europe) to lake area, food availability, and shoreline vegetation complexity. Further, overall mean and maximum species richness increased with nutrient load, as did maximum bird densities across guilds.

Our purpose was to quantify factors potentially attracting birds to stormwater-management ponds on airports in the Pacific Northwest (USA) and to provide guidance on design of future airport stormwater-management structures to reduce the attraction to birds. We hypothesized that avian use of stormwater-management ponds would be explained by 1 or a combination of 5 a priori models composed fully or in part by the following variables: pond surface area; ratio of the area of open water to area of emergent and woody vegetation; perimeter irregularity; and geographic isolation (Tiner, 2003).

\section{Study area}

Because of sample size requirements and the possibility of wildlife hazard management on airports, a confounding factor in quantifying potential attractants to birds, we conducted our study off airport properties within an urban/suburban setting. We selected stormwater-management ponds within Snohomish and King Counties, north of Seattle, Washington (47 $37^{\prime}$ North, $122^{\circ} 20^{\prime}$ West), and approximately $50 \mathrm{~km}$ from Seattle-Tacoma International Airport (SEA). We considered these ponds as surrogates to stormwater-management ponds that are found on SEA and other airports in the region. In Washington, designs of stormwatermanagement structures may vary widely, but all structures must meet requirements set by the U.S. Federal Clean Water Act and the state Water Pollution Control Act (see Washington Department of Ecology, WDE, 2001).

Snohomish County has a total area of $5689 \mathrm{~km}^{2}, 5411 \mathrm{~km}^{2}$ of which is land and $278 \mathrm{~km}^{2}$ (4.9\%) of which is water. The topography of the county includes saltwater beaches, rolling hills, and riverbottom farmlands in the west to dense forest and alpine wilderness in the mountainous east. Sixty-eight percent of the county land area is forest land, $18 \%$ is rural, $9 \%$ is urban/city and $5 \%$ is agri- cultural (http://www1.co.snohomish.wa.us/County_Information/). King County has a total area of $5974 \mathrm{~km}^{2}, 5506 \mathrm{~km}^{2}$ of which is land and $467 \mathrm{~km}^{2}$ (7.8\%) of which is water. The topography of King County is similar to that of Snohomish to the north. Urban areas comprise $1189 \mathrm{~km}^{2}$ of the county (http://www.metrokc.gov/ddes/compplan/). The climate in both counties is a marine-type with mild temperatures year round, ranging on average from $5.1^{\circ} \mathrm{C}$ in winter to $18{ }^{\circ} \mathrm{C}$ during summer. Average annual precipitation is approximately $104 \mathrm{~cm}$, and 50\% or more the year includes sky conditions characterized as partly cloudy or with precipitation. Mean annual wind speed for the region is approximately $2 \mathrm{~km} / \mathrm{h}$.

\section{Methods}

\subsection{Pond selection}

We selected 30 ponds (Fig. 1) that best represented stormwater retention/detention structures on airports in the area. Our pondselection criteria required that (1) a site contained water when first visited; (2) the pond had no islands (ponds with islands offer habitat potentially attractive to nesting waterfowl, such as Canada geese; Smith et al., 1999); (3) the entire perimeter of the pond was readily visible (e.g., not obstructed by overhanging, shoreline vegetation) and an observer could walk the perimeter during a 3-min observation period; (4) the banks of the pond exhibited apparent slope to the water's edge (i.e., generally, at least a 5:1 horizontal run,

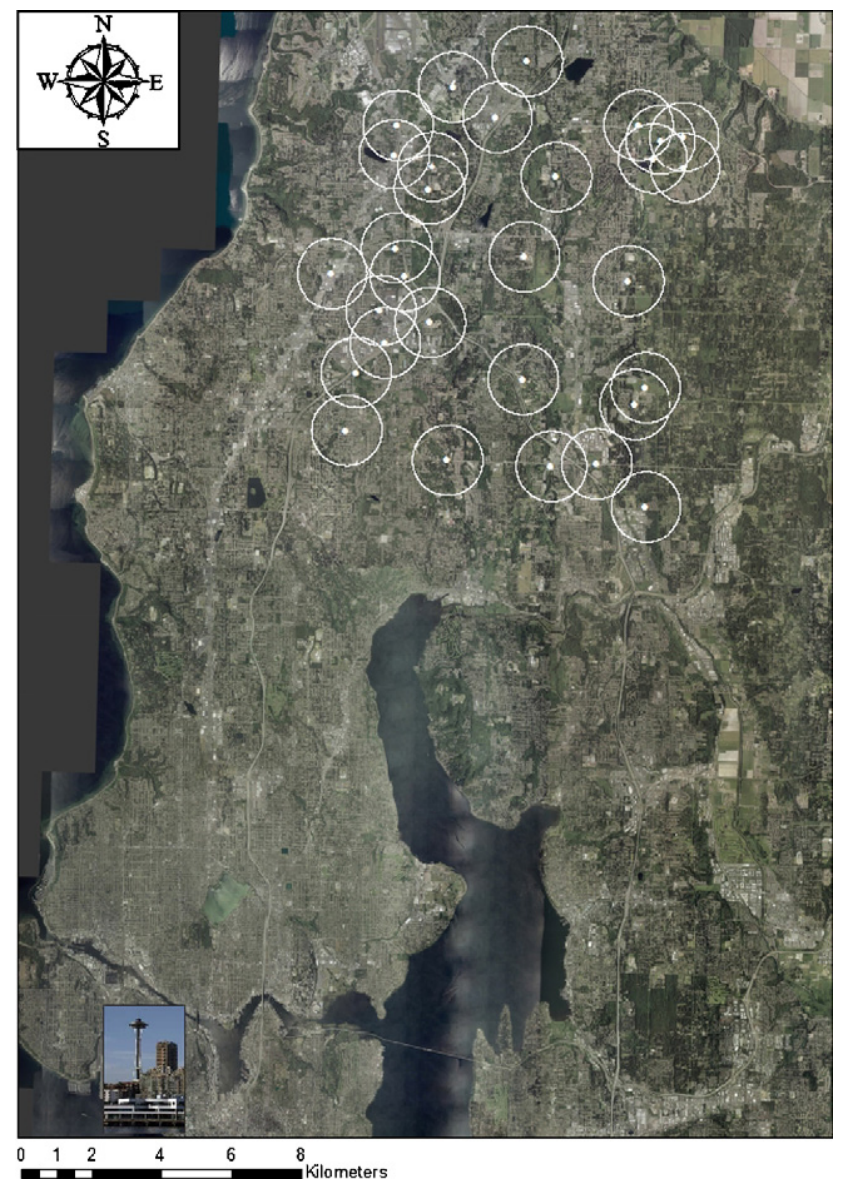

Fig. 1. Stormwater-management ponds within Snohomish and King Counties, north of Seattle, Washington ( $47^{\circ} 37^{\prime}$ North, $122^{\circ} 20^{\prime}$ West), and approximately 50 linear km from Seattle International Airport, that were selected as experimental sites. Each pond is represented as a white dot bounded by a $1-\mathrm{km}$ radius circle. 
$H$ :vertical rise, $V)$; (5) there was at least $0.5 \mathrm{~km}$ separation between study ponds $(\bar{X}$ distance to nearest experimental pond $=1339.7 \mathrm{~m}$, S.D. $=743.5 \mathrm{~m}$ ); and (6) the sample of 30 ponds could be visited by a single observer within a 5 -h period. We note that the maximum recommended slope of interior walls for stormwater-management ponds in western Washington is $3 H: 1 V$ (WDE, 2001).

Importantly, our selection criteria followed FAA recommendations (FAA, 2004; Cleary and Dolbeer, 2005) regarding management of vegetation on and near airport stormwater-management facilities to reduce wildlife use. In addition to obvious concerns over providing food and cover resources to wildlife, the management of vegetation around a stormwater-management pond protects the functionality and physical integrity of the structure (WDE, 2001), and aids wildlife control operations at the site. Our selection criteria were, therefore, unbiased relative to potential avian use of current stormwater-management ponds on airports in the area.

We defined the shoreline slope for each pond at cardinal points by measuring "run" and "rise" from the waterline. For multi-cell ponds (e.g., 2 to 3 contiguous cells) we made our measurements within each cell. We monitored 4 pond sites comprising 2 cells each, and a single pond site with 3 cells. We considered the complex of 2 to 3 cells at a site as the experimental unit. Our study ponds exhibited a mean (S.E.) minimum slope of approximately 29.9\% (25.4\%) or approximately $3.4 \mathrm{H}: 1 \mathrm{~V}$; 5 of the ponds had completely vertical concrete walls. Also, each pond had an access point for maintenance and rescue purposes.

\subsection{Observations at ponds}

Our protocol was to randomly select 4 days within a calendar week for observations and visit all ponds on each day, but alternating between morning ( $30 \mathrm{~min}$ after sunrise) and evening (up to $30 \mathrm{~min}$ after sunset) observation periods. Within a week, morning and evening observations were separated by at least $4 \mathrm{~h}$. We randomly selected a starting pond for the first morning and evening observations of the week, then proceeded to the next pond (i.e., relative to a numerical identification) and, subsequently, through the sample of 30 ponds. For the last 2 observation days within a week, we began at the next pond in our numerical order. We continued this method of timing our visits each week until all 30 ponds served as the starting point on our route; we then repeated the process.

Each observation at a pond entailed an instantaneous count, but allowed 3 min to flush unidentified birds. The count included all avian species using the pond embankment (WDE, 2001) physically in the basin, or hunting over the basin. We did not count birds arriving after the instantaneous count and during a 3-min flush period. Also, we were interested in the probability of use of sites based on frequency of species detection over the study period and relative to our a priori models (see below), not a comparison of absolute numbers of species individuals among sites. Therefore, we converted count data to detection/non-detection (i.e., species detected $=1$; species not detected $=0$ ) for our analysis.

We considered "use" of a site as a product of our sampling effort (i.e., simply detected or not) and distinguishable from biological residency of the site (see MacKenzie, 2005). Important to this definition of "use" is whether the probability of a species being physically present at the pond was random, and not dependent upon survey timing (MacKenzie, 2005 and citations therein). Given our pond-selection criteria, which excluded ponds where visibility of the shoreline was obscured, and our sampling frequency within and across weeks, we contend that the probability of not detecting those species considered hazardous to aviation was negligible. However, our detection of more secretive species (e.g., within Rallidae) was likely biased by a sampling effort not specific to those species (e.g., inclusion of call counts). We considered a species detected and using a pond for any week if a species individual or flock was observed at the pond at least once during that week.

We grouped our species observations relative to foraging guilds (e.g., bay or diving ducks, surface-feeding ducks, wading birds) that reflected American Ornithologist Union classification or, in some cases, species of interest because of documented hazards to aircraft (e.g., waterfowl, gulls, raptors, blackbirds [Icteridae], European starlings [Sturnus vulgaris], doves/pigeons; see Dolbeer et al., 2000; Cleary et al., 2007).

\subsection{Pond characteristics}

In August 2005, we indexed the vegetative community at each pond by sampling within 2 placements of $1-\mathrm{m} \times 1-\mathrm{m}$ frame at each cardinal point (i.e., up to 8 placements per pond). The first placement at each cardinal point was abutting the waterline and the second at a depth of $1 \mathrm{~m}$. Our placement of the frame at a depth of $1 \mathrm{~m}$ was arbitrary. However, we note that the maximum depth at low water for a system classified as palustrine is $<2 \mathrm{~m}$ (Cowardin et al., 1979). If the water level did not reach $1 \mathrm{~m}$, the second measurement was not taken. We visually estimated the proportionate coverage of each plant species and open water within the frame.

Upon each visit to a pond, we recorded an index of water depth, based on a graduated 2.4-m depth stake positioned in the pond's deepest portion. Although we did not select depth directly as an independent variable, this factor was inherently related to other pond characteristics (see below). If a pond comprised cells separated by elevation and dikes, we selected the cell that appeared deepest for placement of the depth stake. For multi-cell ponds, we recorded avian use across all cells as a single experimental unit. In addition, for all ponds, we recorded perimeter of the pond within the basin (including separate chambers). Given the potential dynamic nature of these stormwater-management ponds over short time intervals (e.g., a single day), we defined the perimeter of the pond as comprising the immediate area(s) of water (standing or flowing) or (during dry periods) moist ground, and the vegetation contained therein. A logical extension of this definition would be the inclusion of vegetation external to the physical boundaries of the pond embankment (e.g., timber) if excessive rains flooded the containment system.

We used a satellite image of each pond and geographic information system (GIS; ArcGIS 9.0, ESRI) to contour the pond perimeter at approximately 0.10 -ha increments between potential high- and low-water marks. On each visit to a pond, we then visually estimated the perimeter location relative to the contoured satellite image. If a perimeter estimate fell between contours, the new contour was noted on the photograph. We then visually estimated the proportion of the pond comprising emergent, submergent, woody vegetation, and open water. We also visually estimated ice cover. We converted vegetation, open water, and ice proportions to areas (ha) based on the perimeter estimate and a subsequent calculation of the surface area of the pond. We used the GIS to calculate perimeter and areas of vegetation, open water, and ice. We calculated an irregularity index as the ratio of the pond perimeter to the perimeter of a perfect circle of equal area (Gibbs et al., 1991). In addition, using the GIS, we estimated the closest water resource and type (e.g., palustrine, lacustrine, or riverine; as per Cowardin et al., 1979) within a $1-\mathrm{km}$ radius of each pond.

\subsection{Correlation among variables}

Correlation among pond characteristics can confound inference relative to variable contribution to model fit. For example, pond age, 
bottom substrate, and depth can affect presence and area of emergent and submergent vegetation, as ponds must be seeded, mature, and water levels must be conducive to vegetation growth. Input of runoff over time can layer synthetic, clay, or stone basins with sediment, thus allowing growth of emergent vegetation. Depth can potentially influence avian species use, independently of vegetative coverage. Further, surface area of open water is related to the areas of the various vegetative covers and, indirectly, depth.

To reduce potential multicollinearity among our a priori variables, we calculated the composite variable (e.g., Gibbs et al., 1991), the ratio of area of open water to area of emergent and woody vegetation. We also used PROC CORR and the Pearson Correlation Coefficient (SAS, 1999) to assess correlation between variables within pond and based on weekly means. Variables were retained if the mean (across ponds) $P>0.05$. Importantly, at this point in the analysis we did not evaluate the potential contribution of selected variables to group use of ponds.

We recognize that seasonality is a factor in any species' use of habitat and that some species might be observed only briefly because of seasonal movements. However, our sample size dictated parsimony in the number of variables and models evaluated. We relied on an evaluation of model variables reported as important to a broad scope of avian species in their use of water resources, as well as the frequency of our sampling within and across weeks to evaluate our models across seasons.

\subsection{Model fitting}

Ecological data are generally recognized as often being nonlinear and rarely normally distributed (Gibbs et al., 1991 and citations therein; McKinstry and Anderson, 2002). Therefore, we chose logistic regression to develop models of avian habitat use. We investigated an a priori full model comprising the aforementioned pond characteristics as

$P=\frac{1}{1+\exp \left[-\left(\beta_{0}+\beta_{\text {sa }}+\beta_{\text {ow:ew }}+\beta_{\text {irreg }}+\beta_{\text {isol }}\right)\right]}$,

where $P$ is the probability of use (per group). Here, $\beta_{0}$ represents the intercept, and the subsequent $\beta$ values the coefficients (to be estimated) for the specific predictor variables within the exponent. Specifically, sa is the surface area of the pond/wetland complex; ow:ew is the ratio of area of open water to area of emergent and woody vegetation; irreg is the perimeter irregularity and isol is geographic isolation (see Tiner, 2003), defined as the distance to the nearest water resource (see Cowardin et al., 1979) within a 1-km radius of the pond.

We were interested in the probability, $P$, in the format of the full model as

group detected $=1 \mid \beta_{0}, \beta_{\text {sa }} \beta_{\text {ow:ew }} \beta_{\text {irreg }} \beta_{\text {isol }}$.

We first obtained initial variable estimates for the full model, a set of 4 reduced models, and a mean model (composed of intercept and error only), by using PROC GENMOD (SAS, 1999) and repeated measures regression on the binary data via Generalized Estimating Equations (GEE; SAS, 1999). Our reduced models represented the sequential removal and replacement of each variable in the full model. We selected an autoregressive working correlation structure to represent within-subject correlation over time (Hedeker and Gibbons, 2006). As noted previously, we summarized our data by group for each pond and week.

We used the initial parameter estimates for each model to compose a logistic model, and the linear link function, logit, to express the linear model structure as (Burnham and Anderson, 2002)

$\operatorname{logit}(P)=\log _{\mathrm{e}}\left(\frac{P}{1-P}\right)$.

Variance was distributed as a binomial function. We used PROC NLMIXED (SAS, 1999) to obtain final parameter estimates and the Akaike Information Criterion $\left(\mathrm{AIC}_{\mathrm{C}}\right.$,), which approximates the Kullbach-Leibler (K-L) "best" model (Burnham and Anderson, 2002). We calculated $\triangle \mathrm{AIC}$ values for each model (i.e., $\mathrm{AIC}_{\mathrm{ci}}-\min A \mathrm{AC}_{\mathrm{ci}}$ ) and the associated model weights (i.e., relative likelihood of a model, given the data). Next, we used the model weights to calculate evidence ratios (i.e., the relative likelihood of the best approximating model versus an alternative model). Models were considered distinctive against other models when the evidence ratios differed by a factor $\geq 3$ (Anderson et al., 2000; Burnham and Anderson, 2002). Because we were interested in developing recommendations robust to multi-species use of stormwater-management facilities, we evaluated the same suite of a priori models against pond use by each group.

\section{Results}

We made morning observations prior to $1200 \mathrm{~h}$, and evening observations extended to $2112 \mathrm{~h}$. We obtained data for all but 7 of 53 weeks ( 4 weeks in July 2005, 1 week each in September, October, and November 2005); logistical issues hampered data collection during those 7 weeks, as well as periodically at other times. In total, we made observations at each pond 4 times per week for 23 weeks, 3 observations weekly for 11 weeks, and 2 observations weekly for 11 weeks. Our missing observations were distributed across the 53 weeks of the study.

Our August 2006 sampling effort revealed that the ponds provided vegetative cover (e.g., Typha spp., Scirpus spp.) and food (e.g., Potamogeton spp., Lemna minor, Polygonum spp.) at the waterline and the $1-\mathrm{m}$ depth (on average $25 \%$ and $10 \%$ of the sample areas, respectively; Table 1). Typha spp., Potamogeton spp., and Spirogyra spp. predominated across ponds, but the percentage of open water within the $1-\mathrm{m}^{2}$ sample areas was substantial (waterline: $\bar{X}=53.4 \%$, S.D. $=31.9 \%$; $1-\mathrm{m}$ depth: $\bar{X}=68.5 \%$, S.D. $=38.4 \%$ ). Across observation weeks, our ponds were on average (S.E.; based on weekly means) 0.1 ha (0.06 ha), $1.14 \mathrm{~m}(0.56 \mathrm{~m})$ deep, and composed predominantly of open water $(\bar{X}(\%)$ open water $=73 \%$, S.E. $=23 \%$; ratio of area of open water to area of emergent and woody vegetation $=7.85$, S.E. $=8.96$ ). Pond perimeters were generally irregular $(\bar{X}$ perimeter irregularity $=1.41$, S.E. $=0.36)$, and the closest water resource to most ponds (typically another pond) was on average $316.4 \mathrm{~m}($ S.D. $=214.3 \mathrm{~m})$.

We observed 27 avian species, composing 13 groups, over the 46 weeks, as well as hybrid ducks and geese (Fig. 2). The median number of groups represented per pond each week was 5 (range $=2-8$ groups per pond/week). Surface-feeding ducks and diving ducks predominated in frequency of occurrence $(100 \%$ and $93 \%$, respectively) and numbers observed; other groups were observed at $\leq 50 \%$ of ponds and were few in number (on average $<1$ individual per pond/week; Fig. 2). Likely due to peaks in species annual population sizes and migration, seasonal counts of surface-feeding ducks and diving ducks across ponds were highest during autumn and winter (Fig. 3).

Notably, fewer than 6 individuals of surface-feeding ducks were recorded as mean weekly maximum counts (WMCs) at 28 ponds $(\bar{X}$ WMC across the 28 ponds $=2.0$ individuals, S.E. $=1.6)$; however, 23.3 individuals and 15.3 individuals were recorded as mean WMCs at the remaining 2 ponds, respectively. The 2 ponds exhibited no cover vegetation or a relatively small proportion (average weekly $\bar{X}$ ow: ew across all ponds $=7.8$, S.E. $=9.0 ; \bar{X}$ ow: ew pond $1=5.79$, 
Table 1

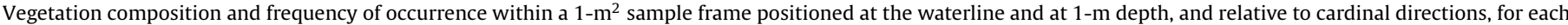
of 30 stormwater-management ponds located north of Seattle, Washington, USA, during August 2005

\begin{tabular}{|c|c|c|c|}
\hline \multirow[t]{2}{*}{ Vegetation $^{\mathrm{a}}$} & \multirow[t]{2}{*}{ Wetland indicator status ${ }^{\mathrm{b}}$} & \multicolumn{2}{|c|}{ Frequency of occurrence (\%) across ponds } \\
\hline & & Waterline & 1-m depth \\
\hline Agrostis spp. & Obligate upland (UPL) & 3.3 & 0.0 \\
\hline Betula spp. & Facultative wetland (FACW) & 3.3 & 0.0 \\
\hline Bryophyta & UPL & 3.3 & 0.0 \\
\hline Carex spp. & OBL/FACW/Facultative & 3.3 & 0.0 \\
\hline Ceratophyllum spp. & OBL & 6.7 & 0.0 \\
\hline Cicuta douglasii & OBL & 3.3 & 0.0 \\
\hline Eleocharis spp. & OBL/FACW & 13.3 & 0.0 \\
\hline Juncus spp. & OBL/FACW & 23.3 & 0.0 \\
\hline Lemna minor & OBL & 16.7 & 0.0 \\
\hline Ludwigia spp. & OBL & 10.0 & 0.0 \\
\hline Myriophyllum spp. & OBL & 6.7 & 3.3 \\
\hline Nymphaea odorata & OBL & 3.3 & 0.0 \\
\hline Phalaris arundinacea & FACW & 10.0 & 0.0 \\
\hline Polygonum spp. & OBL/FACW & 10.0 & 0.0 \\
\hline Potamogeton spp. & OBL & 46.7 & 33.3 \\
\hline Rubus discolor & No Indicator & 6.7 & 0.0 \\
\hline Salix spp. & FACW & 6.7 & 0.0 \\
\hline Scirpus spp. & OBL & 13.3 & 3.3 \\
\hline Spiraea spp. & FACW & 13.3 & 0.0 \\
\hline Spirogyra spp. & OBL & 53.3 & 20.0 \\
\hline Typha spp. & OBL & 36.7 & 13.3 \\
\hline
\end{tabular}

a Includes filamentous algae.

b See Chadde (2002).

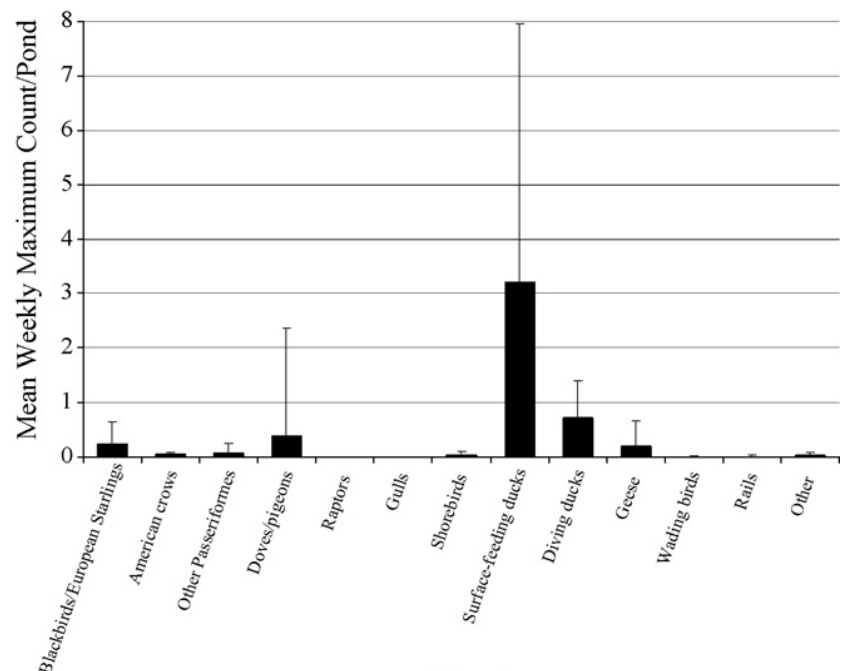

Avian Group

Fig. 2. Mean weekly maximum counts, by pond, of avian groups observed during scheduled morning and evening observation periods at 30 stormwater-management ponds in Snohomish and King Counties, north of Seattle, Washington $\left(47^{\circ} 37^{\prime}\right.$ North, $122^{\circ} 20^{\prime}$ West), USA, between 14 February 2005 and 17 February 2006. Standard errors are noted. Species observations were grouped relative to foraging guilds that reflected American Ornithologist Union classification or, in some cases, species of interest because of documented hazards to aircraft (e.g., waterfowl, gulls, raptors, blackbirds, European starlings, and doves/pigeons; see Dolbeer et al., 2000; Cleary et al., 2007). Composition of avian groups included red-winged blackbird and European starling; American crow; other Passeriformes including the American robin (Turdus migratorius) and house sparrow (Passer domesticus); rock pigeon; red-tailed hawk; glaucous-winged gull (Larus hyperboreus); killdeer; surface-feeding ducks including the green-winged teal (Anas crecca), American widgeon (Anas americana), gadwall (Anas strepera), mallard (Anas platyrhynchos), wood duck(Aix sponsa), northern shoveler (Anas clypeata), and hybrid duck; diving ducks including bufflehead (Bucephala albeola), canvasback (Aythya valisineria), common goldeneye (Bucephala clangula), hooded merganser (Lophodytes cucullatus), and ring-necked duck (Aythya collaris); pied-billed grebe (Podilymbus podiceps) was included in diving duck group; Canada goose (Branta canadensis) and hybrid goose; great blue heron; and American coot. Species in the group "other" included the belted kingfisher, northern flicker, and tree swallow.
S.E. $=3.5 ; \bar{X}$ ow:ew pond $2=0.0 ;$ S.E. $=0.0)$. Also, the 2 ponds exhibited relatively high perimeter irregularity (average weekly $\bar{X}$ irreg across all ponds $=1.4$, S.E. $=0.4 ; \bar{X}$ irreg pond $1=2.4$, S.E. $=0.0 ; \bar{X}$ irreg pond $2=1.7$; S.E. $=0.0$ ).

\subsection{Model comparisons}

Our full model, composed of sa, ow:ew, irreg, and isol, was either the best approximating model or indistinguishable from $\leq 2$ of the remaining 5 models when applied to pond use by 9 of the 13 groups considered (Table 2). For models selected, Akaike weights (i.e., relative likelihoods) ranged from 0.869 to 0.994 . In contrast,

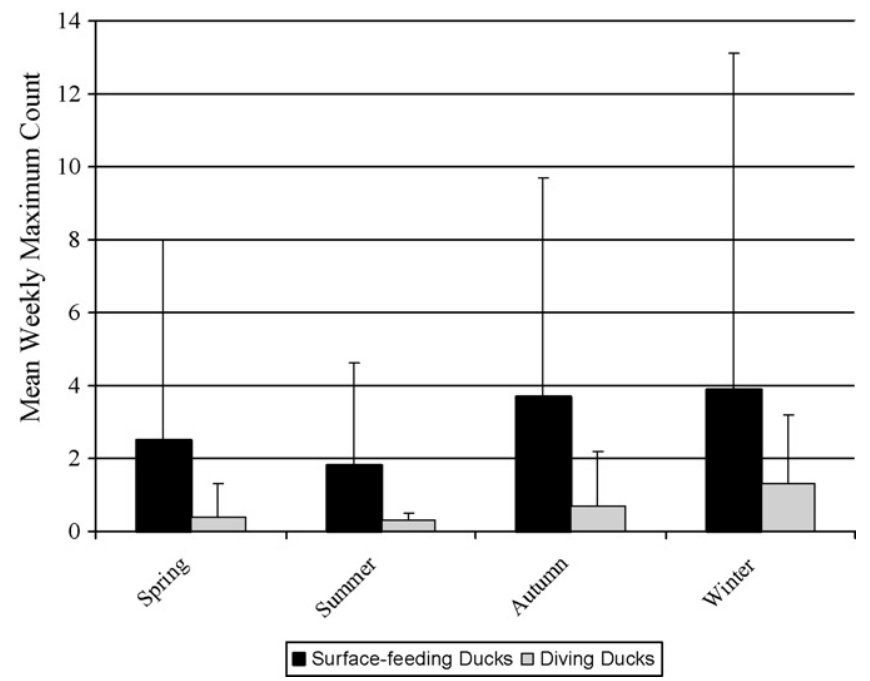

Fig. 3. Mean weekly maximum counts, by season (spring: 22 March-21 June; summer: 22 June-21 September; autumn: 22 September-21 December; Winter: 22 December-21 March), of surface-feeding and diving ducks (see Fig. 2 for species) observed during scheduled morning and evening observation periods at 30 stormwater-management ponds in Snohomish and King Counties, north of Seattle, Washington $\left(47^{\circ} 37^{\prime}\right.$ North, $122^{\circ} 20^{\prime}$ West), USA, between 14 February 2005 and 17 February 2006. Standard errors are noted. 
Table 2

An a priori full model and alternative models composed of parameters ${ }^{\mathrm{a}}$ potentially explaining avian use of a stormwater-management pond

\begin{tabular}{|c|c|c|c|c|c|c|c|c|c|c|}
\hline \multirow[t]{2}{*}{ Group $^{b}$} & \multicolumn{5}{|c|}{ Model parameter estimates (S.E.) } & \multirow[t]{2}{*}{$K$} & \multirow[t]{2}{*}{$\mathrm{AIC}_{\mathrm{c}}$} & \multirow[t]{2}{*}{$\triangle \mathrm{AIC}$} & \multirow[t]{2}{*}{$w_{i}$} & \multirow[t]{2}{*}{ Evidence ratio } \\
\hline & $\beta_{0}$ & sa & ow:ew & irreg & isol & & & & & \\
\hline Blackbird/starling & $\begin{array}{l}-1.7862(0.4697) \\
-1.2261(0.3992) \\
-2.0473(0.4826) \\
-3.4607(0.3341) \\
-1.9785(0.4505) \\
-2.6275(0.1074)\end{array}$ & $\begin{array}{l}4.3709(0.7820) \\
3.9450(0.7551) \\
4.0035(0.7569) \\
2.2272(0.6252)\end{array}$ & $\begin{array}{l}-0.0484(0.0164) \\
-0.0518(0.0168) \\
\\
-0.4484(0.0163) \\
-0.4001(0.0151)\end{array}$ & $\begin{array}{l}-1.6498(0.3686) \\
-0.1627(0.3662) \\
-1.6072(0.3800) \\
\\
-0.4919(0.2807)\end{array}$ & $\begin{array}{l}0.0015(0.0006) \\
0.0017(0.0006) \\
0.0015(0.0006) \\
0.0008(0.0006)\end{array}$ & $\begin{array}{l}6 \\
5 \\
5 \\
5 \\
5 \\
2\end{array}$ & $\begin{array}{l}642.6 \\
646.4 \\
656.0 \\
661.7 \\
670.5 \\
683.3\end{array}$ & $\begin{array}{r}0.0 \\
3.8 \\
13.4 \\
19.1 \\
27.9 \\
40.7\end{array}$ & $\begin{array}{r}0.8689 \\
0.1300 \\
0.0011 \\
<0.0001 \\
<0.0001 \\
<0.0001\end{array}$ & $\begin{array}{l}1.0 \\
6.7 \\
812.4 \\
14044.7 \\
>10^{6} \\
>10^{6}\end{array}$ \\
\hline Surface-feeding ducks ${ }^{c}$ & $\begin{array}{r}-2.9373(0.2805) \\
-2.8018(0.2741) \\
-1.7561(0.1676) \\
-3.1456(0.2917) \\
-2.0947(0.2547) \\
0.1831(0.0541)\end{array}$ & $\begin{array}{l}3.2093(0.4701) \\
3.2285(0.4688) \\
4.6227(0.4116) \\
2.6632(0.4655)\end{array}$ & $\begin{array}{l}0.0096(0.0037) \\
0.0086(0.0037) \\
0.0100(0.0037) \\
0.0069(0.0036)\end{array}$ & $\begin{array}{l}1.0966(0.2030) \\
1.0678(1.0678) \\
1.9049(0.1859) \\
1.1291(0.2050)\end{array}$ & $\begin{array}{l}0.0026(0.0004) \\
0.0025(0.0003) \\
0.0026(0.0004) \\
0.0021(0.0003)\end{array}$ & $\begin{array}{l}6 \\
5 \\
5 \\
5 \\
5 \\
2\end{array}$ & \begin{tabular}{r|}
1693.9 \\
1698.8 \\
1724.1 \\
1742.2 \\
1747.8 \\
1903.6
\end{tabular} & $\begin{array}{r}0.0 \\
4.9 \\
30.2 \\
48.3 \\
53.9 \\
209.7\end{array}$ & $\begin{array}{r}0.9206 \\
0.0794 \\
<0.0001 \\
<0.0001 \\
<0.0001 \\
<0.0001\end{array}$ & $\begin{array}{l}1.0 \\
11.6 \\
>10^{6} \\
>10^{6} \\
>10^{6} \\
>10^{6}\end{array}$ \\
\hline Diving ducks & $\begin{array}{l}-2.0146(0.2804) \\
-2.0317(0.2482) \\
-1.7338(0.1795) \\
-1.8672(0.2716) \\
-2.0580(0.2737) \\
-1.0116(0.0609)\end{array}$ & $\begin{array}{l}2.1299(0.4272) \\
2.1413(0.4184) \\
2.4365(0.3591) \\
2.1591(0.4271)\end{array}$ & $\begin{array}{l}0.0094(0.0036) \\
0.0094(0.0036) \\
0.0090(0.0036) \\
0.0098(0.0036)\end{array}$ & $\begin{array}{l}0.2522(0.1914) \\
0.2520(0.1914) \\
\\
0.2125(0.1895) \\
0.7544(0.1584)\end{array}$ & $\begin{array}{r}<-0.0001(0.0004) \\
<-0.0001(0.0004) \\
-0.0001(0.0004) \\
-0.0004(0.0004)\end{array}$ & $\begin{array}{l}6 \\
5 \\
5 \\
5 \\
5 \\
2\end{array}$ & $\begin{array}{l}1541.1 \\
1552.1 \\
1553.8 \\
1558.6 \\
1577.0 \\
1602.6\end{array}$ & $\begin{array}{r}0.0 \\
11.0 \\
12.7 \\
17.5 \\
35.9 \\
61.5\end{array}$ & $\begin{array}{r}0.9940 \\
0.0041 \\
0.0017 \\
0.0002 \\
<0.0001 \\
<0.0001\end{array}$ & $\begin{array}{l}1.0 \\
244.7 \\
572.5 \\
6310.7 \\
>10^{6} \\
>10^{6}\end{array}$ \\
\hline Rock pigeon & $\begin{array}{l}-5.0646(0.9906) \\
-4.7514(0.9951) \\
-5.6448(0.9246) \\
-1.5210(0.6849) \\
-7.8766(0.8551) \\
-3.9527(0.1980)\end{array}$ & $\begin{array}{r}-1.4083(1.2441) \\
-1.8036(1.1433) \\
1.3825(1.1143) \\
0.2814(1.2028)\end{array}$ & $\begin{array}{l}-0.1417(0.0677) \\
-0.1238(0.6484) \\
-0.1337(0.0649) \\
-0.1255(0.0660)\end{array}$ & $\begin{array}{l}2.0488(0.4248) \\
2.2171(0.4376) \\
2.5128(0.4203) \\
\\
2.5762(0.4420)\end{array}$ & $\begin{array}{l}-0.0089(0.0024) \\
-0.0098(0.0026) \\
-0.0095(0.0025) \\
-0.0120(0.0030)\end{array}$ & $\begin{array}{l}5 \\
6 \\
5 \\
5 \\
5 \\
2\end{array}$ & $\begin{array}{l}195.9 \\
196.6 \\
202.8 \\
217.8 \\
218.4 \\
260.0\end{array}$ & $\begin{array}{r}0.0 \\
0.7 \\
6.9 \\
21.9 \\
22.5 \\
64.1\end{array}$ & $\begin{array}{r}0.5759 \\
0.4058 \\
0.0183 \\
<0.0001 \\
<0.0001 \\
<0.0001\end{array}$ & $\begin{array}{l}1.0 \\
1.4 \\
31.5 \\
56954.0 \\
76879.9 \\
>10^{6}\end{array}$ \\
\hline Geese $^{\mathrm{c}}$ & $\begin{array}{l}-5.1105(0.5517) \\
-5.0643(0.5501) \\
-4.7179(0.5189) \\
-6.0712(0.4972) \\
-2.7231(0.3493) \\
-2.9143(0.1219)\end{array}$ & $\begin{array}{r}-0.4712(0.7554) \\
-0.5005(0.7627) \\
0.1462(0.7462) \\
1.6576(0.6264)\end{array}$ & $\begin{array}{l}0.0154(0.0062) \\
0.0153(0.0062) \\
0.0165(0.0060) \\
0.0104(0.0062)\end{array}$ & $\begin{array}{l}1.8017(0.2715) \\
1.8834(0.2992) \\
1.7816(0.2942) \\
1.9109(0.3009)\end{array}$ & $\begin{array}{l}-0.0030(0.0009) \\
-0.0031(0.0010) \\
-0.0032(0.0010) \\
-0.0031(0.0010)\end{array}$ & $\begin{array}{l}5 \\
6 \\
5 \\
5 \\
5 \\
2\end{array}$ & $\begin{array}{l}505.7 \\
507.3 \\
510.3 \\
517.3 \\
540.6 \\
561.6\end{array}$ & $\begin{array}{r}0.0 \\
1.6 \\
4.6 \\
11.6 \\
34.9 \\
55.9\end{array}$ & $\begin{array}{r}0.6441 \\
0.2894 \\
0.0646 \\
0.0019 \\
<0.0001 \\
<0.0001\end{array}$ & $\begin{array}{l}1.0 \\
2.2 \\
10.0 \\
330.3 \\
>10^{6} \\
>10^{6}\end{array}$ \\
\hline Killdeer & $\begin{array}{l}-6.5648(1.0429) \\
-6.6295(1.0377) \\
-6.5876(1.0842) \\
-8.0525(0.9671) \\
-3.7748(0.6814) \\
-4.2195(0.2252)\end{array}$ & $\begin{array}{l}0.1000(1.2654) \\
0.1029(1.2677) \\
0.9553(1.2743) \\
2.2873(1.1177)\end{array}$ & $\begin{array}{l}-0.0024(0.0185) \\
-0.0024(0.0186) \\
-0.0006(0.0181) \\
-0.0151(0.0211)\end{array}$ & $\begin{array}{l}2.0673(0.4686) \\
2.0687(0.4831) \\
2.0553(0.4936) \\
2.1873(0.5117)\end{array}$ & $\begin{array}{l}-0.0042(0.0019) \\
-0.0042(0.0020) \\
-0.0042(0.0020) \\
-0.0046(0.0020)\end{array}$ & $\begin{array}{l}5 \\
5 \\
6 \\
5 \\
5 \\
2\end{array}$ & $\begin{array}{l}188.1 \\
188.1 \\
190.1 \\
193.4 \\
202.8 \\
211.1\end{array}$ & $\begin{array}{r}0.0 \\
0.0 \\
2.0 \\
5.3 \\
14.7 \\
23.0\end{array}$ & $\begin{array}{r}0.4100 \\
0.4100 \\
0.1508 \\
0.0290 \\
0.0003 \\
<0.0001\end{array}$ & $\begin{array}{l}1.0 \\
1.0 \\
2.7 \\
14.2 \\
1556.2 \\
98715.8\end{array}$ \\
\hline Great blue heron & $\begin{array}{r}3.0105(2.3395) \\
4.1583(2.4256) \\
4.1019(2.3195) \\
-1.0993(1.6967) \\
-4.0963(1.3160) \\
-4.9200(0.3174)\end{array}$ & $\begin{array}{l}3.4968(1.9603) \\
3.7679(2.1134) \\
\\
0.2870(1.8505) \\
6.6728(2.0281)\end{array}$ & $\begin{array}{l}-0.0384(0.0345) \\
-0.0273(0.0245) \\
-0.0122(0.0238) \\
-0.0021(0.0224)\end{array}$ & $\begin{array}{l}-3.2181(1.2199) \\
-3.4652(1.1448) \\
-2.1762(0.9452) \\
-2.1436(1.1957)\end{array}$ & $\begin{array}{l}-0.0333(0.0126) \\
-0.0384(0.0135) \\
-0.0434(0.0124) \\
-0.0264(0.0107)\end{array}$ & $\begin{array}{l}5 \\
6 \\
5 \\
5 \\
5 \\
2\end{array}$ & $\begin{array}{r}92.4 \\
92.5 \\
93.9 \\
99.2 \\
115.3 \\
120.5\end{array}$ & $\begin{array}{r}0.0 \\
0.1 \\
1.5 \\
6.8 \\
22.9 \\
28.1\end{array}$ & $\begin{array}{r}0.4070 \\
0.3872 \\
0.1923 \\
0.0136 \\
<0.0001 \\
<0.0001\end{array}$ & $\begin{array}{l}1.0 \\
1.1 \\
2.1 \\
30.0 \\
93901.3 \\
>10^{6}\end{array}$ \\
\hline
\end{tabular}




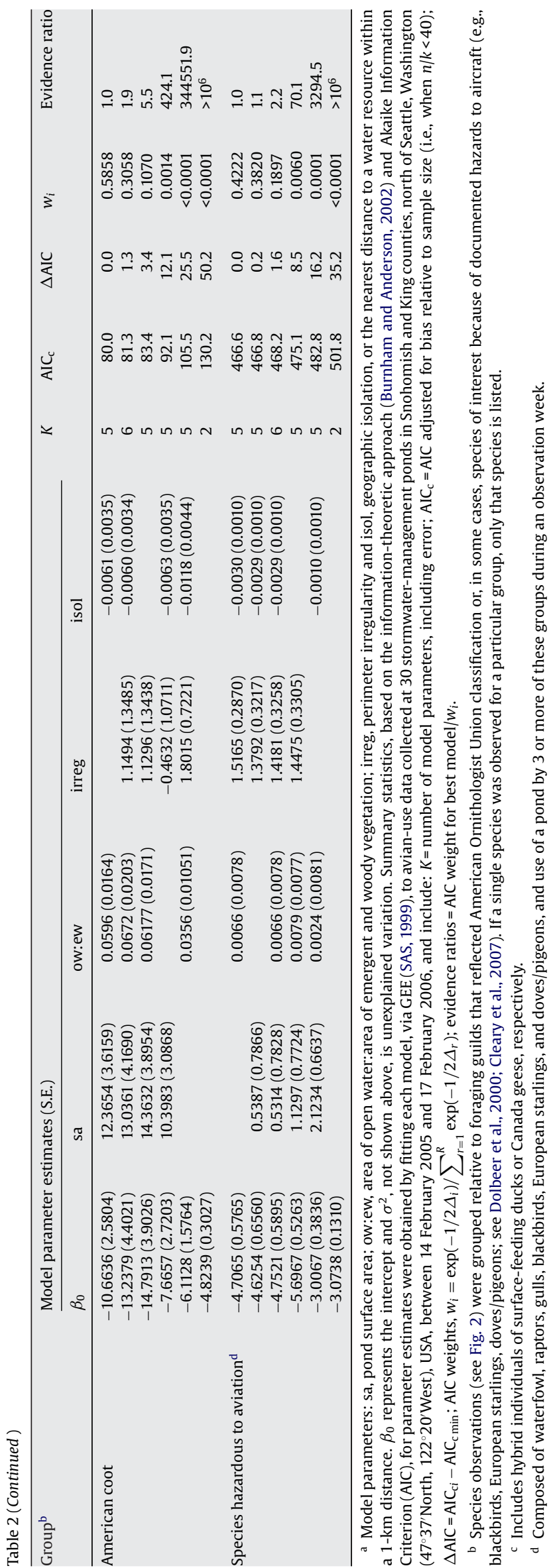

relative likelihood for the mean model (i.e., the model comprising no parameters, only an intercept) was $<10^{-4}$ for all groups. Consequently, comparisons of model fit among our a priori models were biologically and statistically relevant for the 9 groups.

We found no models applicable to pond use by raptors, gulls, American crows (Corvus brachyrhynchos), or "other Passeriformes" (i.e., species other than blackbirds, European starlings, or within Corvidae). Similarly, there was no best approximating model(s) for belted kingfishers (Ceryle alcyon), northern flickers (Colaptes auratus), and tree swallows (Tachycineta bicolor; grouped together as "other" because of rarity of observations of each species individually).

Based on model evidence ratios, pond use by 3 groups (redwinged blackbirds, Agelaius phoeniceus, and European starlings combined, surface-feeding and diving ducks, respectively) was best approximated by the full model (Table 2). For red-winged blackbirds and European starlings, isol, ow:ew, irreg, and sa ranked in successive contribution to model fit, as indicated by increasing evidence ratios in the unselected reduced models (Table 2).

For surface-feeding ducks, the evidence ratio for the reduced model lacking ow:ew indicated that this variable, though important, contributed least to model fit (the contributions of other variables were indistinguishable; Table 2). Interestingly, pond use by surface-feeding ducks was positively correlated with isol. In diving ducks, evidence ratios for reduced models indicated that isol, irreg, ow:ew, and sa ranked in successive contribution to pond use by these species. In contrast to surface-feeding ducks, pond use by diving ducks was negatively correlated with isol.

The full model and a model lacking sa were best approximating models in application to pond use by rock pigeons (Columba livia) and geese, respectively (Table 2 ). Here, sa may be considered as superfluous, whereas evidence ratios for the remaining reduced models indicated that ow:ew, irreg, and isol (rock pigeons), and ow:ew, isol, and irreg (geese) ranked in successive importance.

Also, the full model and models lacking sa or ow:ew best approximated pond use by killdeer (Charadrius vociferous), great blue herons (Ardea herodias), and ponds receiving use by $\geq 3$ avian groups considered hazardous to aviation (Cleary et al., 2007; Table 2). We considered sa and ow:ew superfluous to model fit for these species. Evidence ratios for the unselected reduced models indicated that isol and irreg (killdeer and species hazardous to aviation, respectively), and irreg and isol (great blue herons) ranked successively in contribution to model fit.

Further examination of pond use by species considered hazardous to aviation revealed that estimated probability of use, while varying isol and holding other variables constant, decreased from a maximum of only 0.25 at $0-\mathrm{km}$ separation to $<0.01$ with a $5.0-\mathrm{km}$ separation (Fig. 4a). In contrast, varying irreg while holding other variables constant yielded estimates of probability of use ranging from 0.01 to 1.00 (Fig. 4b).

Finally, the full model and a model lacking irreg best approximated pond use by American coots (Fulica americana; Table 2), though the species was observed only at 2 ponds. We considered irreg superfluous to model fit. In the unselected reduced models, evidence ratios indicated that isol, ow:ew, and sa ranked successively in contribution to model fit.

\section{Discussion}

Management of stormwater runoff on airports is necessary for the safety of aircraft operations, but the containment of runoff can create a wildlife attractant (U.S. Federal Aviation Administration, FAA, 2004). Based on data collected over a 53-week period at 30 stormwater-management ponds characteristic of those on airports 

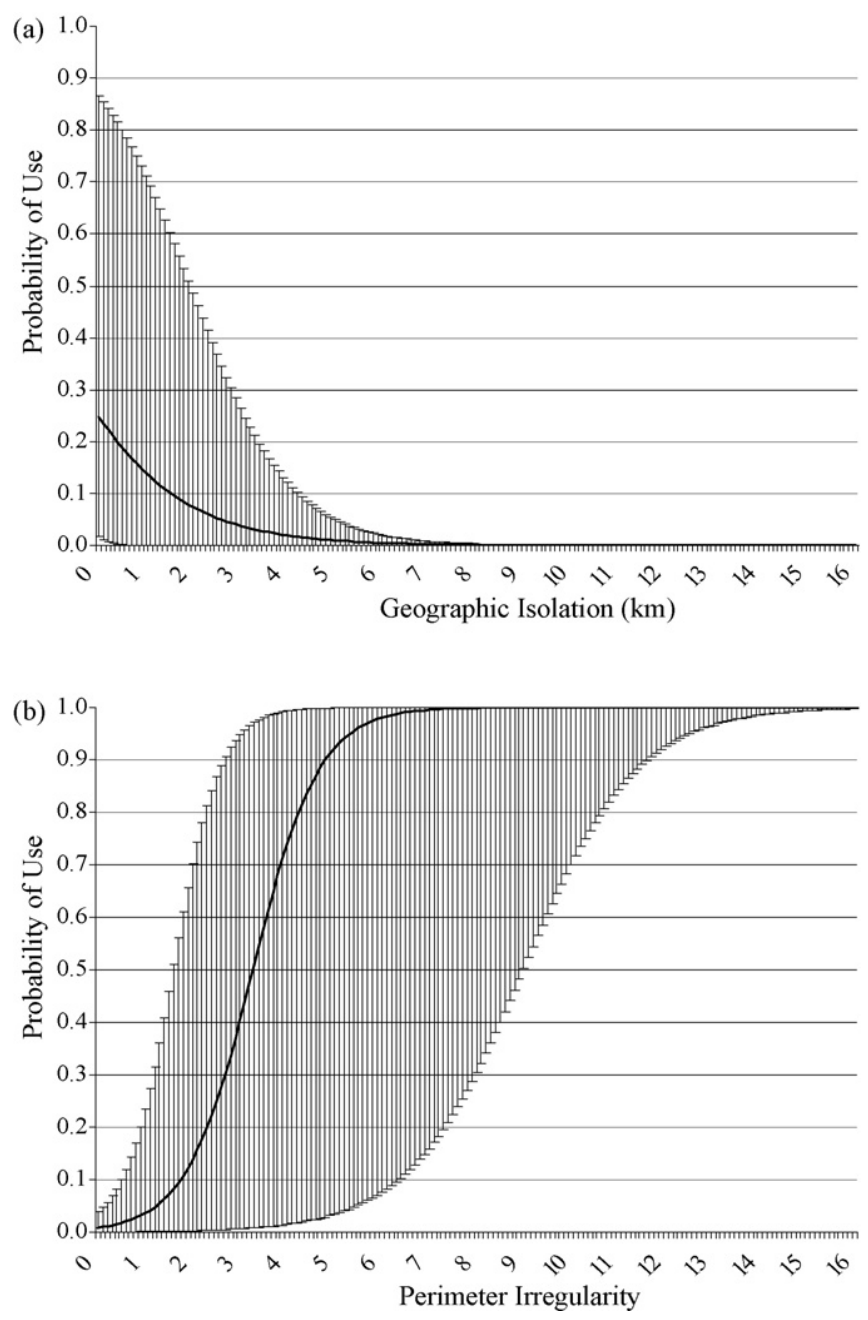

Fig. 4. Probability of pond use, $P$, by species hazardous to aviation, including waterfowl, raptors, gulls, blackbirds, European starlings, and doves/pigeons, and use of a pond by 3 or more of these groups during an observation week. Here, $P=1 /\left\{1+\exp \left[-\left(\beta_{0}+\beta_{\text {sa }}+\beta_{\text {ow:ew }}+\beta_{\text {irreg }}+\beta_{\text {isol }}\right)\right]\right\}$, where $\beta_{0}$, is the intercept $(-4.6552)$; sa, pond surface area (0.3066); ow:ew, area of open water:area of emergent and woody vegetation (0.0040); irreg, perimeter irregularity (1.4361); isol, geographic isolation $(-0.0007)$, or the nearest distance to a water resource within a $1-\mathrm{km}$ distance and $\sigma^{2}$, is unexplained variation. Parameters represent weighted estimates and 95\% Wald confidence limits (PROC NLMIXED; SAS, 1999) of those estimates from model averaging (Burnham and Anderson, 2002) of 3 models representing a combined relative likelihood $>0.990$ and evidence ratios under 2.2 (see Table 2). Functions represent (a) variation in isol and (b) irreg, respectively, while all other parameters were held constant.

in the Pacific NW, we found that a model composed of pond surface area, the ratio of area of open water to area of emergent and woody vegetation, perimeter irregularity, and geographic isolation (i.e., our full model) accounted for use by 9 of 13 avian groups considered. Undoubtedly, factors unrelated to the need for water or the other physical features of our ponds also contributed to species use or avoidance. However, the fit of our full model to pond use by over $69 \%$ of the avian groups considered is a pattern similar to that reported by other researchers (Weller and Spatcher, 1965; Brown and Dinsmore, 1986; Gibbs et al., 1991; Fairbairn and Dinsmore, 2001).

We suspect that the opportunistic nature of the American crow, in combination with habitat factors unassociated with the ponds (e.g., road density and availability of carrion; Verbeek and Caffrey, 2002), likely contributed to infrequent use of our sites and the lack of model fit for this species (Fig. 2). Gulls were also observed infrequently, probably because urban (see Belant et al., 1998) and marine resources (i.e., Puget Sound) were more available west of our sites. As for raptors, we again suspect that resources outside of our ponds were important to habitat use. For example, there is evidence that red-tailed hawk (Buteo jamaicensis) distribution is linked to a composite of prey, low-density plant cover (i.e., vegetation that increases vulnerability of rodents to predation), and perch availability (Preston, 1990; Leyhe and Ritchison, 2004; see also Blackwell and Wright, 2006). In addition, species composing the group "other Passeriformes" were not wetland avifauna and were also observed infrequently.

For both surface-feeding ducks and diving ducks our full model was the best approximating model. We note that Bates et al. (1988), working on floodwater-retarding structures (non-airport structures) in the southern USA, reported that use of impoundments by waterfowl is tied to surface area (particularly sites in excess of $10 \mathrm{ha}$ ), the association of abundant aquatic vegetation for forage and production of macroinvertebrates, and proximity to large reservoirs and refuges (within $1.6 \mathrm{~km}$ ) that serve as stopover points during daily feeding flights.

The positive correlation between use of our ponds by surfacefeeding ducks and pond isolation is suggestive that factors exterior to the ponds (e.g., decreased availability of other water resources) strongly affected use of our sites. In contrast, use of ponds by diving ducks, species likely making longer flights from larger bodies of water (e.g., Puget Sound), was negatively correlated with pond isolation. For both groups, stopover points might have been diminished during the period of our study due to drought conditions in western Washington during 2005 (e.g., precipitation was $<50 \%$ of the monthly average by February 2005 and the snowpack at $<26 \%$ of the monthly average; WDE, 2005).

Importantly, waterfowl rank among the top 5 avian groups most frequently struck by aircraft (Cleary et al., 2007). Our findings highlight the need for airport managers to consider how future stormwater-management facilities might increase resources available to these species, particularly in light of water resources within $1 \mathrm{~km}$ of a planned facility. In addition, the fact that the relatively small areas and shallow depths of our sites attracted waterfowl consistently is indicative that airport managers must control waterfowl access to existing ponds on the AOA via harassment, covering, or drawdown (e.g., as per FAA, 2004).

For sites used by $\geq 3$ groups considered hazardous to aviation (waterfowl, gulls, raptors, blackbirds, European starlings, and doves/pigeons; see Dolbeer et al., 2000; Cleary et al., 2007), the fit of the full model and models lacking surface area or the ratio of open water to vegetative cover were indistinguishable. Geographic isolation and perimeter irregularity were particularly important as features contributing to use by these groups. Clearly, use of our ponds by surface-feeding ducks and diving ducks contributed to model fit for this component of our analysis. However, we note that increased surface area (i.e., $>0.10 \mathrm{ha}$ ) of stormwatermanagement ponds and decreased distance to alternative water resources might enhance foraging and refuge opportunities for a variety of avian species (e.g., our findings for killdeer, great blue herons, and American coots; see also Murkin et al., 1997; Smith et al., 1999; Paracuellos and Tellería, 2004). Further, increased density and proximity of small wetlands (e.g., $\sim 0.4$ ha) can contribute positively to sustaining populations of a variety of wetland species (Gibbs, 1993, 2000). We contend, therefore, that control of the variables composing our full model with regard to design of stormwater-management ponds will contribute to a decrease in bird strikes, particularly with species considered hazardous to aviation. 


\section{Conclusions}

The implication of our findings is that for 9 of 13 avian groups considered in the use of stormwater-management ponds the full model was consistent with prior research on factors contributing to increased avian species richness and diversity in wetland systems. Recognizing the potential constraints of geographic region and engineering considerations (e.g., WDE, 2001), we suggest that all parameters composing our full model be considered in designs of future stormwater-management ponds at airports in the Pacific Northwest (and possibly at other airports in North America). However, the primary focus should be on reducing pond perimeter via circular or linear designs. Ponds should also be located so as to maximize the distance between stormwater-management ponds and other water resources, particularly within $1 \mathrm{~km}$ of a facility. Finally, to minimize avian use of current airport stormwater-management ponds, we suggest that access to open water be reduced by frequent drawdown or use of a cover.

\section{Acknowledgments}

Our work was supported by the U.S. Department of Agriculture, Animal and Plant Health Inspection Service, Wildlife Services (WS), WS National Wildlife Research Center (NWRC), and the FAA, William Hughes Technical Center, Atlantic City, New Jersey, under agreement DTFACT-04-X-90003. BFB and DAL were supported by the NWRC, and LMS and MAL were supported by WS, Olympia, WA. Greg Snelson and Matthew Stevens provided field assistance. Elizabeth Poggiali provided logistical support. We greatly appreciate reviews of earlier drafts of this manuscript by Robert Beason, Patrick Kocovsky, Martin Stapanian, and Lisa Yako.

\section{References}

Adams, L.A., Dove, L.E., Franklin, T.M., 1985a. Mallard pair and brood use of urban stormwater-control impoundments. Wildl. Soc. Bull. 13, 46-51.

Adams, L.A., Dove, L.E., Franklin, T.M., 1985b. Use of urban stormwater impoundments by wetland birds. Wilson Bull. 97, 120-122.

Anderson, D.R., Burnham, K.P., Thompson, W.L., 2000. Null hypothesis testing: problems, prevalence, and an alternative. J. Wildl. Manage. 64, 912-923.

Bates, G., Valentine, G.L., Sprague, F.H., 1988. Waterfowl habitat created by floodwater-retarding structures in the southern United States. In: Weller, M.W. (Ed.), Waterfowl in Winter. University of Minnesota Press, Minneapolis, MN, pp. 419-426.

Belánger, L., Courture, R., 1988. Use of man-made ponds by dabbling duck broods. J. Wildl. Manage. 52, 718-723.

Belant, J.L., Ickes, S.K., Seamans, T.W., 1998. Importance of landfills to urban-nesting herring and ring-billed gulls. Landscape Urban Plan. 43, 11-19.

Blackwell, B.F., Wright, S.E., 2006. Collisions of red-tailed hawks (Buteo jamaicensis), turkey (Cathartes aura), and black vultures (Coragyps atratus) with aircraft: implications for bird strike reduction. J. Raptor Res. 40, 76-80.

Brown, M., Dinsmore, J.J., 1986. Implications of marsh size management and isolation for marsh bird management. J. Wildl. Manage. 50, 392-397.

Burnham, K.P., Anderson, D.R., 2002. Model Selection and Multimodel Inference-A Practical Information-Theoretic Approach, 2nd edition. Springer, New York, NY.
Chadde, S.W., 2002. A Great Lakes Wetland Flora: A Complete Guide to the Aquatic and Wetland Plants of the Upper Midwest, 2nd edition. PocketFlora Press, Laurium, MI.

Cleary, E.C., Dolbeer, R.A., 2005. Wildlife Hazard Management at Airports, 2nd edition. Federal Aviation Administration, Office of Airport Safety and Standards, Airport Safety and Compliance Branch, Washington, DC.

Cleary, E.C., Dolbeer, R.A., Wright, S.E., 2007. Wildlife strikes to civil aircraft in the United States 1990-2006. U.S. Department of Transportation, Federal Aviation Administration, National Wildlife Strike Database Serial Report Number 13 Office of Airport Safety and Standards, Airport Safety and Certification, Washington, DC.

Cowardin, L.M., Carter, V., Golet, F.C., LaRoe, E.T., 1979. Classification of wetlands and deepwter habitats of the United States. United States Fish and Wildlife Service, Biological Services Program, FWS/OBS-79/31.

Creighton, J.H., Sayler, R.D., Tabor, J.E., Monda, M.J., 1997. Effects of wetland excavation on avian communities in eastern Washington. Wetlands 17, 216-227.

Dolbeer, R.A., 2006. Height distribution of birds as recorded by collisions with civil aircraft. J. Wildl. Manage. 70, 1345-1350.

Dolbeer, R.A., Wright, S.E., Cleary, E.C., 2000. Ranking the hazard level of wildlife species to aviation. Wildl. Soc. Bull. 28, 372-378.

Fairbairn, S.E., Dinsmore, J.J., 2001. Local and landscape-level influences on wetland bird communities of the prairie pothole region of Iowa, USA. Wetlands 21, 41-47.

Gibbs, J.P., 1993. Importance of small wetlands for the persistence of local populations of wetland-associated animals. Wetlands 13, 25-31.

Gibbs, J.P., 2000. Wetland loss and biodiversity conservation. Conserv. Biol. 13, 314-317.

Gibbs, J.P., Longcore, J.R., McAuley, D.G., Ringelman, J.K., 1991. Use of wetland habitats by selected nongame waterbirds in Maine. United States Fish and Wildlife Service. Fish and Wildlife Research Publication 9.

Hedeker, D., Gibbons, R.D., 2006. Longitudinal Data Analysis. John Wiley \& Sons, Inc. Hoboken, NJ.

Leyhe, J.E., Ritchison, G., 2004. Perch sites and hunting behavior of red-tailed Hawks (Buteo jamaicensis). J. Raptor Res. 38, 19-25.

MacKenzie, D., 2005. What are the issues with presence-absence data for wildlife managers? J. Wildl. Manage. 69, 849-860.

McKinstry, M.C., Anderson, S.H., 2002. Creating wetlands for waterfowl in Wyoming. Ecol. Eng. 18, 293-304.

Murkin, H.R., Murkin, E.J., Ball, J.P., 1997. Avian habitat selection and prairie wetland dynamics: a 10-year experiment. Ecol. Appl. 7, 1144-1159.

Paracuellos, M., Tellería, J.L., 2004. Factors affecting the distribution of a waterbird community: the role of habitat configuration and bird abundance. Waterbirds 27, 446-453.

Preston, C.R., 1990. Distribution of raptor foraging in relation to prey biomass and habitat structure. Condor 92, 107-112.

SAS, 1999. SAS/STAT ${ }^{\circledR}$ Users Guide, Version 8. Cary, NC.

Smith, A.E., Craven, S.R., Curtis, P.D., 1999. Managing Canada Geese in Urban Environments. Jack Berryman Institute Publication 16, and Cornell University Cooperative Extension, Ithaca, New York, USA.

Suter, W., 1994. Overwintering waterfowl on Swiss lakes: how are abundance and species richness influenced by trophic status and lake morphology? Hydrobiologia 279/280, 1-4.

Tiner, R.W., 2003. Geographically isolated wetlands of the United States. Wetlands 23, 494-516.

U.S. Federal Aviation Administration, 2004. Hazardous wildlife attractants on or near airports. Advisory Circular No. 150/5200-33A.

Verbeek, N.A.M., Caffrey, C., 2002. American crow (Corvus brachyrhynchos). In: Poole, A., Gill, F. (Eds.), The Birds of North America, No. 647. The Birds of North America, Inc., Philadelphia, PA.

Washington Department of Ecology, 2001. Stormwater Management Manual for Western Washington. Water Quality Program, Publication Numbers 99-11 through 99-15. Olympia, WA

Washington Department of Ecology, 2005. Drought report, recommendations, and archive. http://www.ecy.wa.gov/programs/wr/ws/wtrsuply.html. Accessed 10 October 2007.

Weller, M.W., Spatcher, C.E., 1965. Role of habitat in the distribution and abundance of marsh birds. Iowa Agricultural and Home Economics Experimental Station Special Report 43. 